frequency necessary to obtain sustained improvement. Until further information is available we recommend that portable hyperbaric chambers must be used only to facilitate but not to delay descent when illness occurs at high altitude.

We thank the Sezione Varallo of the Italian Alpine Club for providing the locations in the Capanna Margherita, and the Swiss Army for transporting some of the equipment.

This study was supported by a grant from the research institute of the Swiss School of Sports, Magglingen, and by grant 3200-0092.85 from the Swiss National Science Foundation.

1 Hackett PH, Rennie D, Levine HD. The incidence, importance, and prophylaxis of acute mountain sickness. Lancet 1976;ii:1149-54.

2 Maggiorini M, Bühler B, Walter M, Oelz O. Prevalence of acute mountain ickness in the swiss alps. BM7 1990;301:853-5.

3 Hackett PH, Rennie D, Grover RF, Reeves JT. Acute mountain sickness and the edemas of high altitude: a common pathogenesis. Respir Physiol 1981;46:383-90

4 Sutton JR, Lassen N. Pathophysiology of acute mountain sickness and high altitude pulmonary oedema: an hypothesis. Bull Europ Physiopathol Respir 1979;15:1045-52.

5 Bärtsch P, Vock P, Maggiorini M, Franciolli M, Fretz C, Schobersberger W, et al. Respiratory symptoms, radiographic and physiologic correlations at high altitude. In: Sutton JR, Coates G, Remmers JE, eds. Hypoxia: the adaptions. Toronto: BC Decker Inc, 1990:241-45.

6 Gamow RI, Geer GD, Kasic JF, Smith HM. Methods of gas-balance control to be used with a portable hypertaric chamber in the treatment of high altitude be used with a portable hyperbaric chamber in the

7 Taber RL. Protocols for the use of portable hyperbaric chamber for the treatment of high altitude disorders. Fournal of Wilderness Medicine 1990; $181-92$.

8 King SJ, Greenlee RR. Successful use of the Gamow hyperbaric bag in the treatment of altitude illness at Mount Everest. fournal of Wilderness Medicin 1990;1:193-02

\section{Relationship between adult victims of assault and children at risk of abuse}

\section{Lisa Ward, Jonathan P Shepherd, Alan M Emond}

Department of Community Child Health, United Bristol Healthcare Trust, Bristol BS8 1QB Lisa Ward, senior house officer Alan M Emond, consultant community paediatrician

\section{Department of Oral} Surgery, Medicine, and Pathology, University of Wales College of Medicine, Cardiff CF4 4XY Jonathan P Shepherd, professor of oral and maxillofacial surgery

Correspondence to: Dr Emond.
Domestic violence is known to be linked with abuse and neglect of children, and its occurrence has been used to detect vulnerable children before abuse occurs. Surveys of victims of violence have shown a preponderance of single young men, ${ }^{2}$ who are often in fights and consume more alcohol than controls matched for age and sex. ${ }^{3}$ We investigated the extent to which adult victims of violence are members of families in which children are known to be at risk of abuse.

\section{Methods and results}

During 1986-9 we prospectively collected data from adults who attended the accident and emergency department of Bristol Royal Infirmary with injuries resulting from violence. We interviewed the patients at initial attendance and at follow up and recorded details of the assault, police involvement, the patients' alcohol

Details of adult victims of assault recorded in accident and emergency department of Bristol Royal Infirmary during 1986

\begin{tabular}{lc}
\hline & No of subjects ( $\mathbf{n}=535)$ \\
\hline Men & 456 \\
Women & 79 \\
Mean age (years) & 24 \\
(range) & $(15-80)$ \\
Ethnic group: & 493 \\
White & 19 \\
Afro-Caribbean & 5 \\
Asian & 4 \\
Other & 18 \\
Unknown & \\
Employment: & 129 \\
Manual & 183 \\
Other & 139 \\
Unemployed & 19 \\
Student & 15 \\
Housewife & \\
\hline
\end{tabular}

9 Robertson JA, Shlim DR. Treatment of moderate acute mountain sickness with pressurization in a portable hyperbaric (Gamow) bag. Journal of Wilderness Medicine 1991;2:268-73.

10 Sampson JB, Cymerman A, Burse RI, Maher JT, Rock PB. Procedures for the measurement of acute mountain sickness. Aviat Space Environ Med 1983;54:1063-73.

11 SAS Institute. SAS/STAT guide for personal computers. Version 64. Cary, ed. North Carolina: SAS Institute, 1987.

12 Herry JP, Jean D, Kayser B, Bärtsch P. Effect of a 3-hour recompression a 220 mbar on acute mountain sickness during climbing Mont-Blanc. Int 7 Sports Med 1992;13:83. (Abstract.)

13 Birmingham Medical Research Expeditionary Society Mountain Sicknes Study Group. Acetozolamide in control of acute mountain sickness. Lance $1981 ;$ i: $180-93$.

14 Johnson TS, Rock PB. Acute mountain sickness. $N$ Engl $f$ Med 1988;319: $841-5$.

15 Bärtsch P, Baumgartner R, Waber U, Maggiorini M, Oelz O. Controlled trial of breathing $\mathrm{CO} 2$-enriched, $\mathrm{O} 2$-enriched and normal air in the treatment of acute mountain sickness. Lancet 1990;336:772-5.

16 Grover $R$ Tucker A Reeves JT. Hypobaria: an etiologic factor in acute mountain sickness. In: Lowppky JA, Riedesel ML, eds. Oxygen transpon to human tissue. New York: Elsevier, 1982:223-30.

17 Hackett PH, Roach RC, Goldberg S, Greene ER, Selland M, Wilson N, et al. A portable, fabric hyperbaric chamber for treatment of high altitude pulmonary oedema. In: Sutton JR, Coates G, Remmers JE, eds. Hypoxia: the adaptions. Toronto: BC Decker Inc, 1990:291. (Abstract.)

18 Milledge JS, Bryson EI, Catley DM, Hesp R, Luff N, Minty BD, et al. Sodium balance, fluid homeostasis and the reninaldosterone system during prolonged exercise of hill walking. Clin Sci 1982;62:595-04.

19 Bärtsch P, Maggiorini M, Schobersberger W, Shaw S, Rascher W, Girard J, et al. Enhanced exercise-induced rise of aldosterone and vasopressin preceding mountain sickness. 7 Appl Physiol 1991;71:136-43.

20 Reeves JT, Groves BM, Sutton JR, Wagner PD, Cymerman A, Malconian $\mathrm{MK}$, et al. Operation Everest II: preservation of cardiac function at extreme MK, et al. Operation Everest 11: prese.

21 Schoene RB, Lahiri S, Hackett PH, Peters RM, Milledge JS, Pizzo CJ, et al Relationship of hypoxic ventilatory response to exercise performance on Mount Everest. $₹$ Appl Physiol 1984;56:1478-83.

(Accepted 8 February 1993)

consumption, and their demographic and family characteristics. ${ }^{4}$ With the ethical committee's approval, we compared the names and dates of birth of the 535 adult victims of assault recorded during 1986 with data from Avon child protection register. When we found a match we took further information from the register. This lists children who are or have been at risk of abuse, their siblings, and adults closely associated with them. At the time of the study (before new guidance was issued ${ }^{5}$ ) the register's categories were physical, sexual, or emotional abuse; neglect; and grave concern.

Most of the 535 adult victims of assault were young white men injured in street fights; only $15 \%$ of the patients were women (table). Eighteen of the adults (nine men and nine women) were listed on the child protection register. This $1: 1$ ratio of men to women was significantly different from the 30:1 ratio among the adult victims overall ( $p<0.05, t$ test). There was no difference in age, employment status, or ethnic background between the victims who were on the register and those who were not. Eight of the nine women listed on the register knew their assailant: three were boyfriends, two husbands, two colleagues, and one an exhusband. Five women were assaulted by their current partner, and three of these men had convictions for violence or rape, two being schedule 1 offenders (previous convictions for child abuse).

The 18 adults listed on the register were associated with children registered under the following categories: sexual abuse (three), physical abuse (seven), grave concern (six), and both sexual and physical abuse (one). One child was not categorised. Four of these children were considered to be at risk at the time of the study. The others were no longer thought to be at risk and their files were dormant.

\section{Comment}

Although only $3.3 \%$ of the adult victims of assault were recorded on the child protection register, our results have important implications. We studied adult victims of assault who attended hospital in one year, and this represents only a small fraction of all domestic violence. ${ }^{5}$ The data suggest that mothers of children on the register are more at risk of being assaulted than 
mothers not listed on the register. This should be remembered by doctors when they identify risk indicators and formulate action plans at case conferences.

Our study suggests that the children of women who have been assaulted are in need of increased protection. Staff in accident and emergency departments and general practitioners should be aware of the increased risk to children of victims of assault. When women seek medical treatment for injuries resulting from domestic violence the local child protection register should be checked, and if the victim or the assailant is listed the protection of the children in the family must be ensured.
We thank $\mathrm{Mr} \mathrm{R}$ Greenland, custodian of Avon child protection register, for his cooperation and support.

1 Browne K, Saqui F. Approaches to screening for child abuse and neglect. In: Browne K, Davies C, Stratton S, eds. Early prediction and prevention of child abuse. Chichester: John Wiley and Sons, 1988:57-85.

2 Borland M. Violence in the family. Manchester: Manchester University Press, 1976.

3 Hough M, Mayhew P. British crime survey. London: HMSO, 1985. (Home Office research study No 76.)

4 Shepherd JP, Shapland M, Scully C, Leslie IJ. Pattern, severity and aetiology of injury in assault. $7 R$ Soc Med 1990;28:75-8.

5 Department of Health. Working together: a guide to arrangements for interagency cooperation for the protection of children from abuse. London: HMSO, 1991.

(Accepted 9 February 1993)

\section{Should sewage workers and carers for people with learning disabilities be vaccinated for hepatitis $\mathbf{A}$ ?}

\section{J M Poole, A T Shakespeare}

Occupational Health Department, Central Clinic, Dudley DY2 7BX C J M Poole, consultant occupational physician A T Shakespeare, occupational health nurse

Correspondence to: Dr Poole.

BMF 1993;306:1 102
Immunisation against hepatitis $A$ with the newly developed vaccine of inactivated virus is recommended for people visiting parts of the world where the disease is endemic. It has been suggested that sewage workers and carers for people with learning disabilities may also benefit. ${ }^{12}$ There is little empirical evidence to support these recommendations apart from two reports of hepatitis in workers in contact with sewage sludge, the organic end product of sewage treatment. ${ }^{34} \mathrm{We}$ therefore undertook a cross sectional study to compare the prevalence of antibodies to hepatitis A virus in these two occupational groups with the prevalence in controls matched for age and social class.

\section{Subjects, methods, and results}

Forty sewage workers (gully cleaners, jetters, drain repairers, and cesspit emptiers) and 53 carers for children or adults with learning disabilities from two local authorities in the west midlands volunteered for the study after we had explained its purpose. The sewage workers' mean age was $42 \cdot 2$ (range $21-58$ ) years and the carers' $41 \cdot 3(19-63)$ years. We recruited 18 road workers (tarmac layers and pavers) aged $38 \cdot 7(20-62)$ years from one local authority as controls for the sewage workers and 20 office workers (in the personnel department) aged 41.0 (23-64) years as controls for the carers. We chose these controls to match the social class of the sewage workers and carers.

We took $10 \mathrm{ml}$ of blood from each subject. This was allowed to clot, and hepatitis A virus IgG was measured in the serum by enzyme linked immunosorbent assay (ELISA) (Syva MicroTrak total anti-HAV assay, Sorin Biomedica SpA, Italy). Cut off values were established according to the manufacturer's instructions by

Presence of antibodies to hepatitis $A$ virus (determined by ELISA) in sewage workers, carers for people with learning disabilities, and controls. Figures are numbers of subjects

\begin{tabular}{|c|c|c|}
\hline & \multicolumn{2}{|c|}{ Hepatitis A virus IgG } \\
\hline & Present & Absent \\
\hline Sewage workers for local authorities & 23 & 17 \\
\hline Dudley & 14 & 10 \\
\hline Wolverhampton & 9 & 7 \\
\hline Carers for people with learning disabilities & 19 & 34 \\
\hline Carers for adults & 13 & 20 \\
\hline Carers for children & 6 & 14 \\
\hline Controls & 13 & 25 \\
\hline Road workers & 6 & 12 \\
\hline Office workers & 7 & 13 \\
\hline
\end{tabular}

reference to control serum (Syva). Results for the groups were analysed by odds ratios.

The table shows the numbers of subjects who were seropositive for hepatitis A virus. Seropositivity was significantly more prevalent in the sewage workers than the controls (odds ratio 2.60 (95\% confidence interval 1.04 to 6.51$)$ ) but not in the carers for people with learning disabilities (odds ratio $1.07(0.45$ to $2 \cdot 58)$ ). The ratio of seropositive to seronegative subjects was the same in both control groups. No subject had been immunised against hepatitis $A$ in the previous six months.

\section{Comment}

Although the number of subjects was small, the results indicate a significantly increased risk of infection with hepatitis A virus for sewage workers. Operators of high pressure water hoses used to unblock drains (jetting) may be infected from the aerosols generated since they frequently do not wear the respiratory protection provided. Sewage workers may also be infected from their equipment and protective clothing, which are often contaminated with faeces. Furthermore, they eat food in the sewage wagons and may not remove protective clothing before eating in the canteen. Smoking is also permitted at work. As a result of this study our department is undertaking the health education of sewage workers and the immunisation of those who are seronegative.

Selection bias among the sewage workers was eliminated by including all those employed by the two local authorities. Although most of the carers for people with learning disabilities from one of the authorities took part in the study, a selection bias here cannot be excluded. It would be interesting to test a larger sample of sewage workers for an association between length of employment and infection with hepatitis A virus, but the type of work done may be more relevant to the risk of infection. Infection with hepatitis A virus can now be added to leptospirosis (Weil's disease), giardiasis, ${ }^{5}$ and industrial waste as occupational hazards for sewage workers in Britain. Carers for people with learning disabilities seem to be at no greater risk of infection with hepatitis A virus than the general population.

We thank Mr S Farley and Mr P Stewart for performing the ELISA tests and Mr I Calvert for statistical advice.

1 Tilzey AJ, Palmer SJ, Barrow S, Perry KR, Tyrell H, Safary A, et al. Clinical trial with inactivated hepatitis $A$ vaccine and recommendations for its use. BMF 1992;304:1272-6.

2 Hepatitis A; a vaccine at last [editorial]. Lancet 1992;339:1198-9.

3 Timothy EM, Mephan P. Outbreak of infective hepatitis amongst sewage sludge spreaders. Communicable Disease Repon 1984;3:3.

4 Skinhoj P, Hollinger FB, Hovind-Hougen K, Lous P. Infectious liver disease in three groups of Copenhagen workers: correlation of hepatitis $\mathrm{A}$ infection to sewage exposure. Arch Environ Health 1981;36:139-43.

5 Heap BJ, McCulloch MLB. Giardiasis and occupational risk in sewage workers. Lancet 1991;338:1152.

(Accepted 4 March 1993) 